\title{
Fast surveillance response and genome sequencing reveal the circulation of a new Yellow Fever Virus sublineage in 2021, in Minas Gerais, Brazil
}

Miguel S. Andrade ${ }^{1}$, Fabrício S. Campos ${ }^{2}$, Cirilo H. de Oliveira ${ }^{3}$, Ramon Silva Oliveira ${ }^{3}$, Aline A. S. Campos ${ }^{4}$, Marco A. B. Almeida ${ }^{4}$, Danilo Simonini-Teixeira ${ }^{5}$, Anaiá da P. Sevá, Andrea Oliveira Dias Temponi ${ }^{6}$, Fernando Maria Magalhães ${ }^{6}$, Danielle Costa Capistrano Chaves ${ }^{6}$, Maira Alves Pereira ${ }^{7}$, Ludmila Oliveira Lamounier ${ }^{7}$, Givaldo Gomes de Menezes ${ }^{6}$, Sandy Micaele Aquino Teixeira ${ }^{3}$, Maria Eduarda Gonçalves dos Santos ${ }^{3}$, Sofía Bernal-Valle ${ }^{5}$, Nicolas F. D. Müller $^{8}$, Jader da C. Cardoso ${ }^{4}$, Edmilson dos Santos ${ }^{4}$, Maria A. Mares-Guia9, George R. Albuquerque $^{5}$, Alessandro P. M. Romano ${ }^{10}$, Ana C. Franco ${ }^{8}$, Bergmann M. Ribeiro ${ }^{1}$, Paulo M. Roehe $^{8}$, Filipe V. S. Abreu ${ }^{3 *}$

${ }^{1}$ Baculovirus Laboratory, Department of Cell Biology, Institute of Biological Sciences, University of Brasilia, Brasília, Distrito Federal, 70910-900, Brazil

2 Bioinformatics and Biotechnology Laboratory, Campus of Gurupi, Federal University of Tocantins, Gurupi, Tocantins, 77410-570, Brazil

${ }^{3}$ Insect Behavior Laboratory, Federal Institute of Northern Minas Gerais, Salinas, Minas Gerais, 39560-000, Brazil

${ }^{4}$ State Center of Health Surveillance, Rio Grande do Sul State Health Department, Porto Alegre, Rio Grande do Sul, 90610-000, Brazil

${ }^{5}$ Department of Agricultural and Environmental Sciences, Santa Cruz State University, Ilhéus, Bahia, 45662-900, Brazil

${ }^{6}$ State Arbovirus Surveillance Coordination, Minas Gerais State Health Department, Belo Horizonte, Minas Gerais, 31630-901, Brazil

${ }^{7}$ Central Public Health Laboratory (LACEN-MG), Fundação Ezequiel Dias, Belo Horizonte, Minas Gerais, 30510-010, Brazil

${ }^{8}$ Institute of Basic Health Sciences, Federal University of Rio Grande do Sul, Porto Alegre, Rio Grande do Sul, 90050-170, Brazil

${ }^{9}$ Flavivirus Laboratory, Instituto Oswaldo Cruz, Fiocruz, Rio de Janeiro, Rio de Janeiro, 21040360, Brazil

${ }^{10}$ General Coordination of Arbovirus Surveillance, Ministry of Health, Brasília, Distrito Federal, 70058-900, Brazil

*Corresponding author: Filipe Vieira Santos de Abreu, email: filipe.vieira@ifnmg.edu.br

\begin{abstract}
Yellow fever virus (YFV) exhibits a sylvatic cycle of transmission involving wild mosquitoes and non-human primates (NHP). In Brazil, YFV is endemic in the Amazon region, from where waves of epidemic expansion towards other Brazilian states eventually occur. During such waves, the virus usually follows the route from North to the Central-West and Southeast Brazilian regions. Amidst these journeys, outbreaks of Yellow Fever (YF) in NHPs, with spillovers to humans have been observed. In the present
\end{abstract}


work, we describe a surveillance effort encompassing the technology of smartphone applications and the coordinated action of several research institutions and health services that succeeded in the first confirmation of YFV in NHPs in the state of Minas Gerais (MG), Southeast region, in 2021, followed by genome sequencing in an interval of only ten days. Samples from two NHPs (one of the species Alouatta caraya in the municipality of Icaraí de Minas and the other of the species Callithrix penicillata in the municipality of Ubaí) were collected and the presence of YFV was confirmed by RT-qPCR. We generated three near-complete by Nanopore sequencer MinION. Phylogenetic analysis revealed that all viral genomes recovered are equal and related to lineage South America 1, clustering with a genome detected in the Amazon region (Pará state) in 2017. These findings reveal the occurrence of a new wave of viral expansion in MG, six years after the beginning of the major outbreak in the state, between 2015-2018. No human cases were reported to date, showing the importance of coordinated work between local surveillance based on available technologies and support laboratories to ensure a quick response and implementation of contingency measures towards avoiding the occurrence of YF cases in humans.

Keywords: Yellow fever virus, Arbovirus, Flavivirus, Non-human primate, Epizootic, Smartphone

\section{1) Introduction}

In Brazil, the yellow fever virus (YFV, family Flaviviridae, genus Flavivirus) exhibited two epidemiologically distinct transmission cycles, urban and sylvatic, although the former must be mentioned here from a historical perspective. In the urban cycle, which has not been recorded since 1942, the virus is transmitted among humans by the vector Aedes aegypti (Franco, 1969; Monath and Vasconcelos, 2015). In the sylvatic/jungle cycle, the virus is transmitted by wild mosquitoes (mainly Haemagogus and Sabethes) to non-human primates (NHPs, e.g. Alouatta and Callithrix genera) and, occasionally, to unvaccinated humans in close contact with forest areas. Yellow fever (YF) is considered endemic in the tropical rainforest of the Amazon region, from where waves of epidemic expansion spread towards other Brazilian regions at irregular intervals of time (Possas et al., 2018). During these waves, the virus usually reaches the states of 
Goiás (Central-West) and Minas Gerais (Southeast region). Sometimes, the virus arrives in other southeast states, such as São Paulo (in the years 2000, 2008-2009, 2017-2018) (Vasconcelos et al., 2001; Camargo-Neves et al., 2005; de Souza et al,. 2011; Moreno et al., 2011; Romano et al., 2014; Moreno et al., 2015; Cunha et al., 2019), Rio de Janeiro and Espírito Santo (between the years 2017 and 2019) (Fernandes et al., 2017; Gómez et al., 2018; Abreu et al., 2019b; Delatorre et al., 2019), and even the southernmost states of the country, Rio Grande do Sul (2001, 2008-2009, 2020-2021) (Almeida et al., 2012; Vasconcelos et al., 2003; Andrade et al., 2021), Paraná e Santa Catarina (2018-2020) (Ministry of Health Brazil, 2021). The expansion of YF outside the endemic areas raises, at least, three main concerns: 1) the possibility of re-emergence of an urban cycle; 2) the increased risk of YF in humans due to heterogeneous vaccination coverage outside the Amazon region; 3) the risk of extinction of threatened NHP species, especially from the genus Alouatta, highly susceptible to YFV (Holzmann et al., 2010; Almeida et al., 2012; Romano et al., 2014; Bicca-Marques et al., 2017; Dietz et al., 2019; Strier et al., 2019; Berthet et al., 2021).

During the expansion waves, the state of Minas Gerais (MG) has been an important corridor through which the virus travels before spreading to other Brazilian states (Delatorre et al. 2019). In recent times, major outbreaks occurred in MG in 20002003, 2010, and between 2015-2018 (Fig. 1A), the latter being the largest sylvatic outbreak in the last 80 years (Causey et al., 1949; Vasconcelos et al., 2001; Costa, 2005; Ribeiro and Antunes, 2009; Pinheiro et al., 2019; Cunha et al., 2019). In the 2015-2018 outbreak, two viral sub-lineages were detected, crossed MG by different paths: the $\mathrm{YFV}_{\mathrm{MG} / \mathrm{SP} / \mathrm{RS}}$ sub-lineage traveled through the West and Southwest of the state, before reaching the state of São Paulo; the $\mathrm{YFV}_{\mathrm{MG} / \mathrm{ES} / \mathrm{RJ} / \mathrm{BA}}$ sub-lineage, spread by the Northwest, North, Northeast, and East of the state, before reaching the states of Espírito Santo and Bahia (Delatorre et al., 2019; Goes de Jesus et al., 2020; Andrade et al., 2021). Although epizootics have been constantly reported since the end of 2020 (without the opportunity for sample collection), the last reported viral detection in MG occurred in the first semester of 2018 (Delatorre et al., 2019; Minas Gerais, 2021).

In this work, we describe a surveillance effort encompassing the technology of smartphone applications and the coordinated action of State Arbovirus Surveillance Coordination of Minas Gerais State Health Department, Central Public Health Laboratory (LACEN-MG), Ministry of Health of Brazil, and members of Project "Febre Amarela BR" (Portuguese for "Yellow Fever BR") that succeeded in the first confirmation of YFV 
in NHPs in the state of Minas Gerais (MG) in 2021, followed by genome sequencing, in an interval of only ten days. Anticipating our findings, phylogenetics analysis reveals the introduction of a new sub-lineage in the extra Amazonian region.

\section{2) Material and Methods}

\section{1) Study area}

This study was carried out in the state of Minas Gerais, which concentrates the largest number of municipalities (853) in Brazil, the second largest population in the country $(21,411,923$ inhabitants or $10.1 \%$ of the Brazilian population), and the fourth largest geographic extension $(586,513.993 \mathrm{~km} 2$, larger than Spain, for example) (https://www.ibge.gov.br/cidades-e-estados/mg.html). The area covered by this study belongs to the North region of Minas Gerais State, which is predominantly covered by Cerrado (a savannah-like biome) (Figure 1). The region has well-defined dry and rainy periods, with December presenting the highest average rainfall during the summer, and August, the month of this investigation, the driest month of the year, during the winter. 

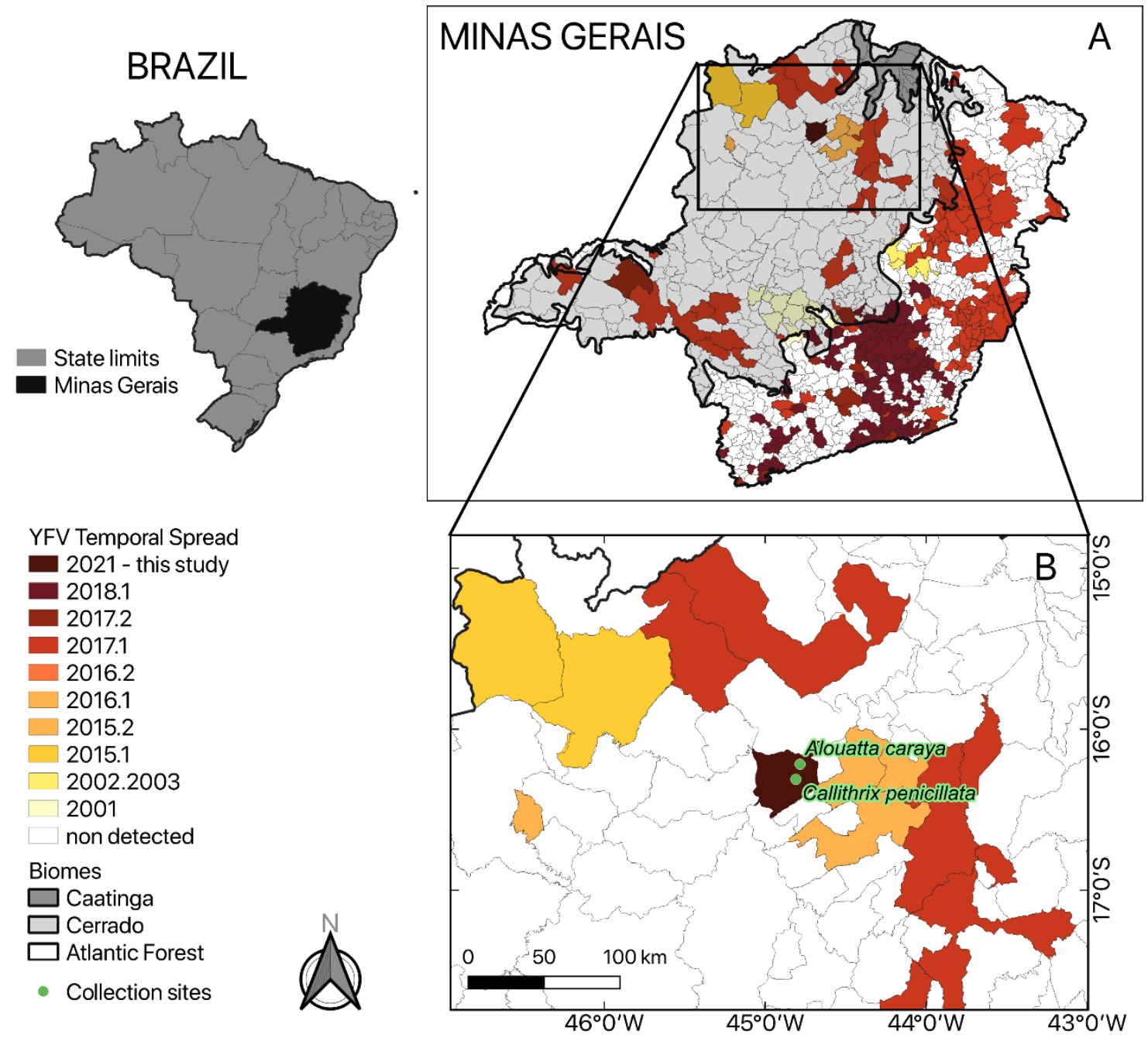

Figure 1. On the left, the Brazil map highlights Minas Gerais (MG) state. The Brazilian regional division consists of states and municipalities grouped into regions. A) MG state map showing different municipalities with YFV detections in NHP and/or humans between 2001 to present (see the caption on the left). In gray are shown the different biomes of MG (Caatinga, Cerrado, and Atlantic Forest). B) Location of epizootics in Minas Gerais state registered on the SISS-Geo platform during this investigation.

\section{2) Building an information network to strengthen epizootic surveillance in northern Minas Gerais}

Since 2020, we have started the organization of an information network linked to a research project called Febre Amarela BR (Yellow fever BR), with the objective of aggregating research institutions, municipal, state, and federal health agencies, in addition 
to the general population, to strengthen the surveillance of epizootics (Abreu et al., 2019a; Abreu et al., 2019c).

For these purposes, we organized preliminary field expeditions to several municipalities in Minas Gerais. In each municipality, meetings and lectures were organized with health agents and environmental surveillance agents, aiming to inform the teams about the importance of epizootics surveillance. The agents were trained to notify epizootics using the SISS-Geo web app (Chame et al., 2019). SISS-Geo is the abbreviation of "Sistema de Informação em Saúde Silvestre Georreferenciado" in Portuguese or "Georeferenced Wildlife Health Information System", which is a platform that works as a public repository for collaborative surveillance of wild animals in Brazil, for the registration of animals occurrences sending pictures of dead or alive animals, and also metadata. The app collects real-time geographic coordinates and sends the information to state and federal surveillance centers. We also organized field works to train the teams to perform vectors and NHP sample collection. Finally, several groups were created in the WhatsApp application with all municipal health agents reached through the meetings, constituting an information network, to send educational material about vector-borne diseases and to exchange news about epizootics (Abreu et al., 2019c). An organization chart showing the steps for organizing the network is shown in Figure 2. All field expeditions were carried out within the scope of the Yellow Fever BR project, with the support of the State Health Department and its regional coordinators.

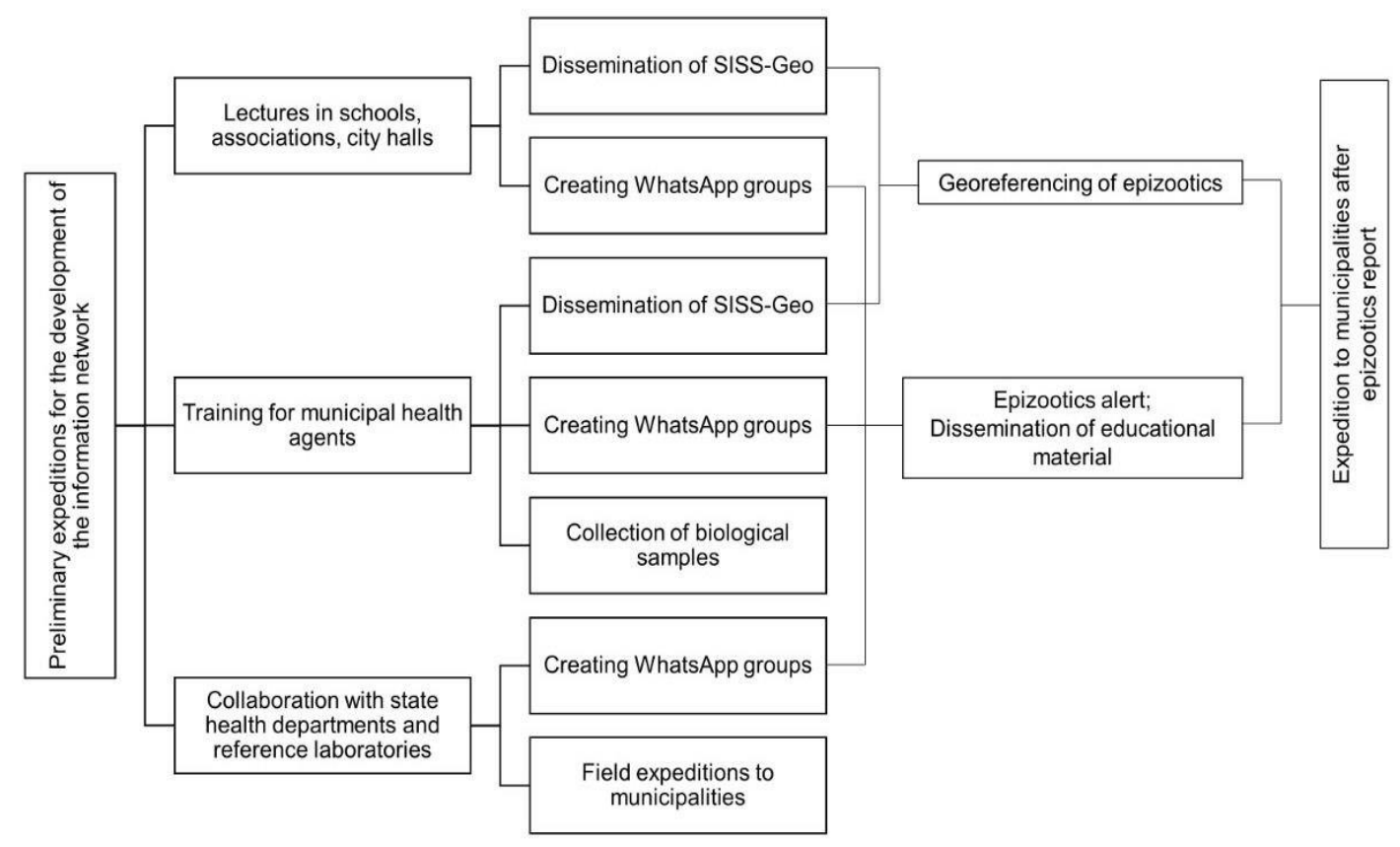


Figure 2. Organization chart showing steps for organizing the information network to strengthen yellow fever surveillance

\section{3) Investigation of epizootic in Northern MG}

On August 24, 2021, the information network alerted us about the occurrence of epizootics in the municipalities of Icaraí de Minas and Ubaí, located in the northern region of Minas Gerais, $595 \mathrm{~km}$ from Belo Horizonte, the capital of the state. Interestingly, these municipalities were not affected by the 2015-2018 outbreak. Focusing on a timely sampling, an expedition was rapidly organized on the following morning, August 25th, 2021, composed of members of the Febre Amarela BR project, members of the state health department, and agents from the affected municipalities. On August 25th and 26th of 2021, we surveyed the riparian forests of the places searching NHP carcasses for the collection of biological samples. The detected epizootics were properly registered in the SISS-Geo app and in the Brazilian Information System on Notifiable Diseases (SINAN). Samples were collected following safety protocols (Brasil, 2017), preserved in liquid nitrogen $\left(-196^{\circ} \mathrm{C}\right)$ and sent to the reference laboratory of the national public health system, whose destination in Minas Gerais was the Ezequiel Dias Foundation (FUNED) as well as to the Baculovirus Laboratory, a branch of the research project Febre Amarela BR for viral diagnosis, at University of Brasilia.

\section{4) Molecular diagnosis}

Samples (different viscera fragments) were lysed with Trizol ${ }^{\mathrm{TM}}$, stored in liquid nitrogen and sent to the sequencing laboratory in dry ice $\left(-80^{\circ} \mathrm{C}\right)$. Total RNA extraction with Trizol ${ }^{\mathrm{TM}}$ was performed following the manufacturer's instructions. YFV RNA detection was done using two previously published RT-qPCR protocols (Domingo et al., 2012).

\section{5) Genome sequencing}

Samples with CT $<25$ were submitted to cDNA synthesis protocol using LunaScript $^{\mathrm{TM}}$ RT SuperMix Kit (NEB) following the manufacturer's instructions. Then, a multiplex tiling PCR was performed using the previously published YFV primers (Faria et al., 2018) and 40 cycles (denaturation: $95^{\circ} \mathrm{C} / 15 \mathrm{~s}$ and annealing/extension: $65^{\circ} \mathrm{C} / 5 \mathrm{~min}$ ) of PCR using Q5 high-fidelity DNA polymerase (NEB). Amplicons were purified using 
$1 \times$ AMPure XP beads (Beckman Coulter), and cleaned-up PCR product concentrations were measured using a QuantiFluor ${ }^{\circledR}$ dsDNA System assay kit on a Quantus ${ }^{\mathrm{TM}}$ Fluorometer (Promega). DNA library preparation was performed using the Ligation sequencing kit SQK-LSK309 (Oxford Nanopore Technologies) and the Native barcoding kit (EXP-NBD104 and EXP-NBD114; Oxford Nanopore Technologies, Oxford, UK). The sequencing library (23 samples and a negative control per run) was loaded onto an R9.4 flow cell (Oxford Nanopore Technologies) and sequenced between 6 to 18 hours using MiNKOW software. The RAMPART (Version 1.2.0, ARTIC Network) package was used to monitor coverage depth and genome completion. The resulting Fast5 files were basecalled and demultiplexed using Guppy (Version 4.4.2, Oxford Nanopore Technologies). Variant calling and consensus genome assembly were carried out with Medaka (Version 1.0.3, Oxford Nanopore Technologies) using the sequence JF912190 as the reference genome.

\section{6) Phylogenetic analyses}

To perform phylogenetic analyses, we selected all near-complete YFV sequences from NCBI ( $n=381$, excluding sequences $<8 \mathrm{~kb}$ and those of vaccine and patent-related viruses). Metadata as samples collection date and geographic coordinates were retrieved from GenBank files or from genome associated publications (manual curation). Genomes MG67-L combined with the 381 genomes from NCBI were aligned with MAFFT v.7.480 (Katoh and Standley, 2013). The Maximum-likelihood tree was inferred using IQTREE, with the GTR $+\mathrm{F}+\mathrm{I}+\Gamma^{4}$ model. The new genome sequences were sent to the NCBI GenBank database under accession numbers OL519587 to OL519589.

\section{3) Results}

On August 25, 2021 (day 1), we notified an epizootic affecting six black-and-gold howler monkeys (Alouatta caraya) in Icaraí de Minas, of which only one was suitable for sampling (liver, spleen, kidney samples were collected and named MG66-L, MG66-S, and MG66-K, respectively). On August 26 (day 2), another epizootic was detected, affecting six black-pincelled marmosets (Callithrix penicillata) in Ubaí and we were able to collect samples from one (liver, spleen, kidney and brain, named MG67-L, MG67-S, MG67-k and MG67-B, respectively). Samples were sent to the laboratory (September 02, day 9) and tested (September 03, day 10). All tissues sampled were positive for YFV by RT-qPCR (Table 1). 
Table 1. RT-qPCR test results, according to tested species, local, tissues, date, and Ct.

\begin{tabular}{cccccc}
\hline Host species & Municipality & $\begin{array}{c}\text { Geographical } \\
\text { coordinates }\end{array}$ & Sample & Collection date & Ct \\
\hline $\begin{array}{c}\text { Alouatta caraya } \\
\text { (MG66) }\end{array}$ & Icaraí de Minas & $16^{\circ} 13^{\prime} 03.3^{\prime \prime} \mathrm{S}$ & Liver & $25 / 08 / 2021$ & 15 \\
& & $44^{\circ} 47^{\prime} 009^{\prime \prime} \mathrm{W}$ & Spleen & $25 / 08 / 2021$ & 14 \\
& & Kidney & $25 / 08 / 2021$ & 20 \\
\hline $\begin{array}{c}\text { Callithrix } \\
\text { penicillata } \\
\text { (MG67) }\end{array}$ & Ubaí & $16^{\circ} 18^{\prime} 42.0^{\prime \prime} \mathrm{S}$ & Liver & $26 / 08 / 2021$ & 31 \\
& & $44^{\circ} 48^{\prime} 36.0^{\prime \prime} \mathrm{W}$ & Spleen & $26 / 08 / 2021$ & 30 \\
& & & Kidney & $26 / 08 / 2021$ & 31 \\
& & & Brain & $26 / 08 / 2021$ & 29 \\
\hline
\end{tabular}

The interval between the alert of our information network and diagnosis was 10 days (Figure 3). After confirming the detection of the virus, health authorities were immediately communicated. Intensified control and investigation actions in the affected and surrounding areas were implemented. Meanwhile, the sequencing library was prepared on the same day and applied to the sequencer resulting in an 8-hour interval between RNA extraction and first read generated.

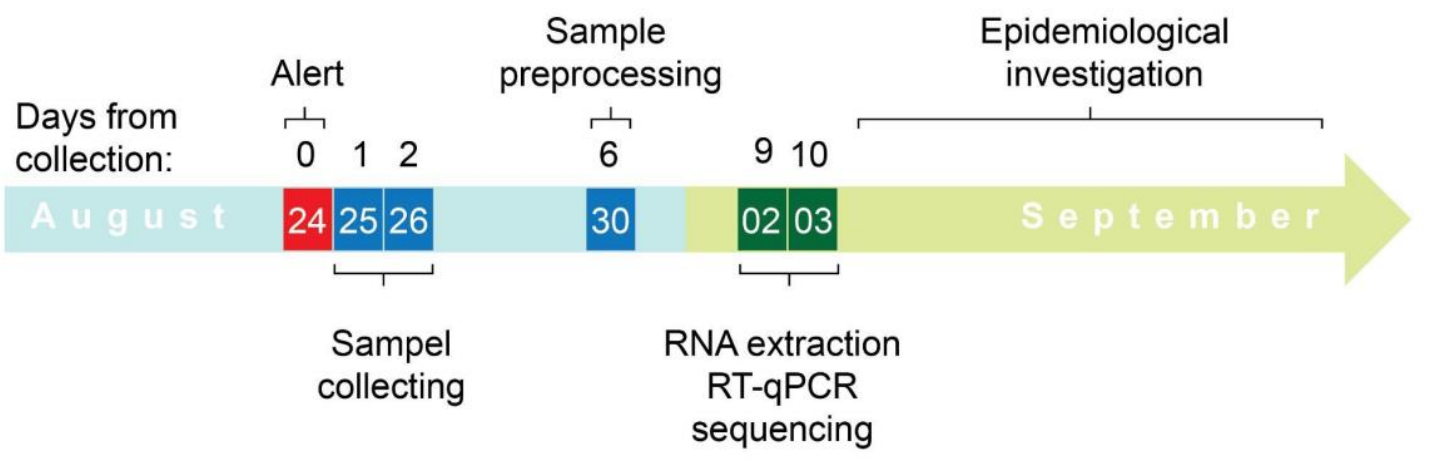

Figure 3. Timeline showing the time spent from the collection of samples until the generation of near-complete genomes.

Three near-complete YFV genomes were generated from different viscera of the same animal: MG66-Liver, MG66-Spleen, and MG66-kidney. The three YFV genomes of Alouatta caraya (MG66) were compared and revealed no intra-host sequence differences. Therefore, for phylogenetic analyses, the MG66-L genome was used. 
Phylogenetic analysis revealed that the YFV genomes generated here were related to the lineage South America 1, as expected, and clustered with an isolate from NHP (Alouatta caraya) identified in Pará (Amazonian region) in 2017 (Figure 4) showing that they are not related to the viruses detected on this same year (2021) in the state of Rio Grande do Sul, the southernmost state of Brazil (Andrade, 2021). These results indicate the circulation of at least two sub-lineages of YFV in the extra amazon region in 2021.

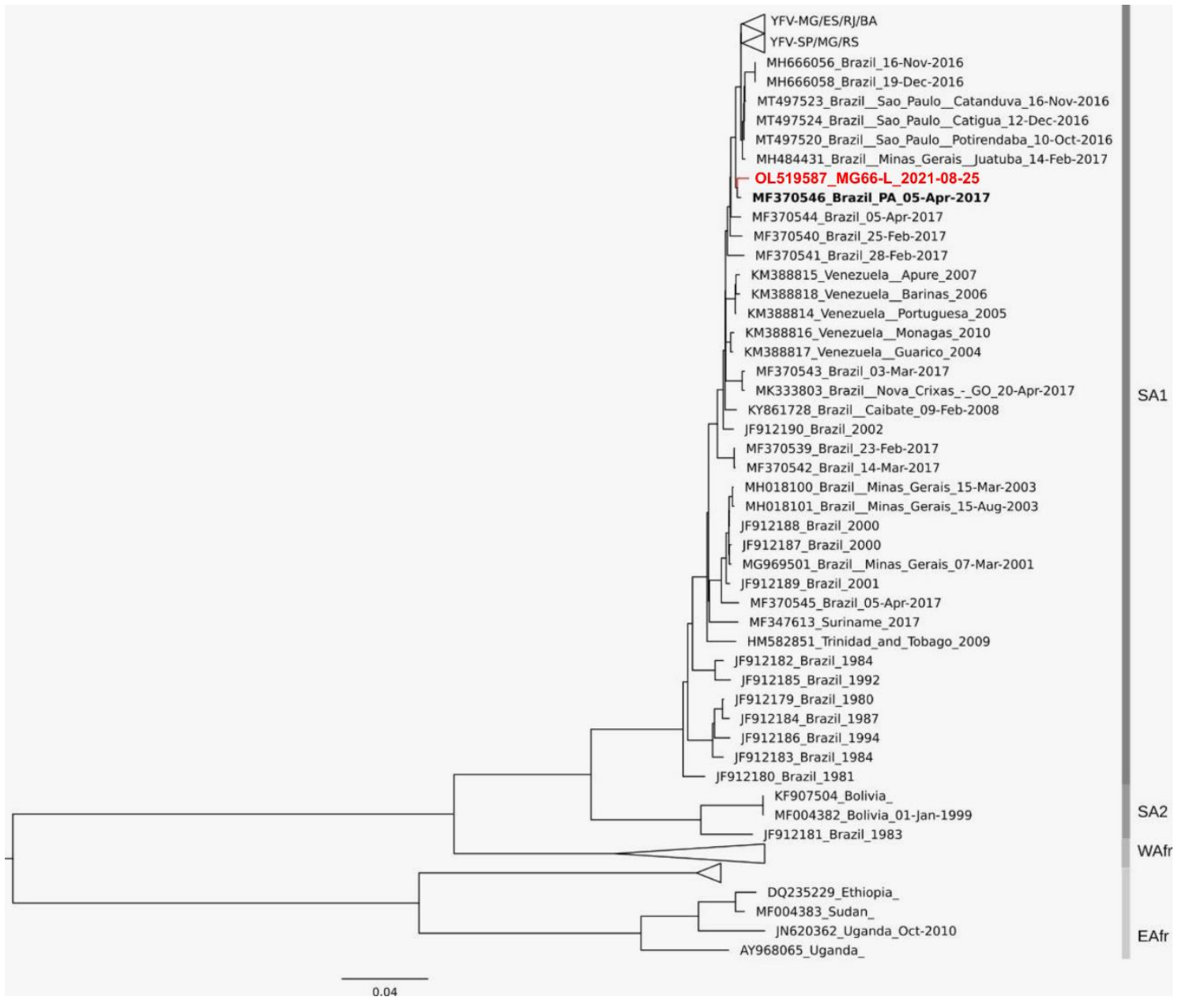

Figure 4. Phylogenetic tree of YFV based on MG66-Liver and NCBI genomes. The

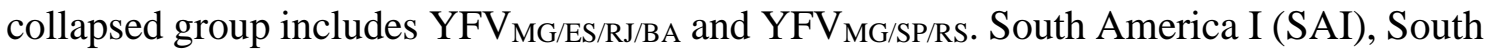
America 2 (SA2), West Africa (WAfr), and East Africa (EAfr) genotypes are indicated. YFV MG/2021 is highlighted in red and is related to the lineage SA1, the same present in the Amazon region in 2017. The sub-lineages that caused the 2015-2021 outbreak $\left(\mathrm{YFV}_{\mathrm{MG} / \mathrm{SP} / \mathrm{RS}}\right.$ and $\left.\mathrm{YFV}_{\mathrm{MG} / \mathrm{ES} / \mathrm{RJ} / \mathrm{BA}}\right)$ are shown at the top of the tree.

\section{3) Discussion}


The state of Minas Gerais has been historically affected by several introductions of the YFV. However, logistical limitations make it difficult to carry out surveillance and the timely collection of biological samples, which requires a robust field and laboratory surveillance system. In the present work, we describe a result of the construction of an inter-institutional network capable of collaborative actions to investigate epizootics, from detection and sample collection to genomic sequencing. The rapid outbreak response (only 10 days between the alert of an epizootic and genome sequencing) carried out in August/2021 resulted in the first confirmation of the circulation of YFV in the state of Minas Gerais in 2021 and showed that the recovered viral genome belongs to the sublineage that circulated in Pará in 2017 (now called $\mathrm{YFV}_{\mathrm{PA} / \mathrm{MG}}$ ).

The state of Minas Gerais has played a role as a YFV spreading route during the expansion waves from the Amazon region. Interestingly, there have been studies of viral spread routes in the region since 1938-1943 (Suppl. Fig. 1) (Causey et al., 1949).

In the last two decades, outbreaks were recorded in 2001 (32 human cases), 2002 to 2003, (63 human cases), and two isolated cases between 2008-2009. However, the largest outbreak was recorded between 2016-2018, with 1006 human cases, and 448 confirmed epizootics (Costa, 2005; Ribeiro and Antunes, 2009; Minas Gerais, 2018; Minas Gerais, 2019). Importantly, there were no records of previous viral circulation in the two currently affected municipalities, which may indicate the presence of a naive NHP population (Fernandes et al., 2021; Mares-Guia et al., 2020).

Since 2019, as far as we know, despite the notification of several epizootics, no new confirmations of YFV circulation occurred in the north of MG (Minas Gerais, 2021). The wide territorial extension, with huge rural areas far from urban and research centers, combined with socioeconomic inequality and the lack of trained professionals in several municipalities make it difficult to implement agile and uniform surveillance of epizootics, diminishing the chances of timely sample collection for virus detection. These characteristics reinforce the need to use new tools and strategies to strengthen surveillance. Among them, worth it to mention: a) the use of smartphone applications to notify epizootics and collect the geographic coordinates of the occurrence in real time. In this sense, the SISS-Geo app, which has been progressively implemented in Brazil, speeds up the arrival of information to involved institutions and provides accurate geographic location, streamlining outbreak response (Chame et al., 2019); b) the use of messaging apps such as Whatsapp to increase the number of "watchers". Creating Whatsapp groups with local or regional reach, composed by different members of the 
population (health agents, cyclists, hikers, students, rural workers, etc.) increases the chances of detecting an epizootic and speeds up the dissemination of important information such as vaccination campaigns and monkey conservation efforts (Abreu et al., $2019 \mathrm{~b}$ and c); c) creation of multi-institutional networks to facilitate and speed up sample collection and diagnosis. In the present work, research institutions linked to the Febre Amarela BR project collaborated with municipal, state, and federal health secretariats. With this joint effort, in the space of 10 days, it was possible to detect and notify the epizootic, collect samples in a distant and isolated region, carry out the molecular diagnosis, disseminate the results to the local governments, and generate the near complete genome of the virus and its phylogeographic relationship (called real-time genomic surveillance). Thus, measures to protect the population, such as the expansion of vaccination coverage, urban vector control, and educational campaigns were triggered immediately by Minas Gerais health authorities, mitigating the risk of YF human cases.

The implementation of real-time genomic surveillance showed that the virus circulating in Minas Gerais is related to the lineage that circulated in the state of Pará, in the Amazon region, in 2017. Therefore, it is a new wave of viral expansion in MG, six years after detection in 2015, when the virus actively spread through the state until 2018. Interestingly, in 2021, at least two different viral sub-lineages circulating at the same time

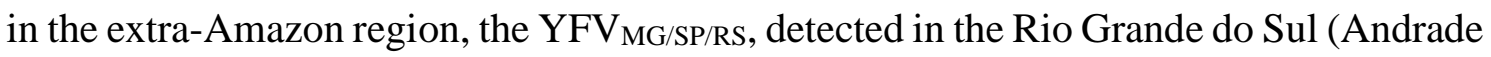
et al., 2021), and YFV noteworthy that the virus was detected at the height of the dry season, and in one of the driest regions of MG, which makes it difficult for the main species of mosquito vectors to survive.

Here, in this brief report, we can see the importance of coordinated work between the municipal health secretariats, the state health secretariat, and support laboratories. Through this system, it was possible to collect the PNH samples, process them and quickly give a result for YFV enabling the taking of protective measures by the competent agents. The genomic surveillance showed that it is a new wave of expansion of the YFV in Minas Gerais, which must be monitored in order to improve preventive actions such as elevating the vaccine coverage in humans and improve communication about the YFV risk to health professionals and the general population, in order to avoid human cases in other areas of Minas Gerais and Brazil. Also, this should improve the sensibilization about the importance of the non-human-primates as sentinels as for YFV presence in the region. Finally, this study shows the importance of collaborative, integrated surveillance, 
allowing prompt action, even in challenging situations, with stakeholders able to support and answer time on the yellow fever surveillance and response.

Author Contributions: Conceived and designed the experiments: F.V.S.A, M.S.A., F.S.C., A.A.S.C., J.C.C., E.S., D.S.T., G.R.A., A.C.F., B.M.R., P.M.R. and M.A.B.A. Performed the experiments: M.S.A., M.A.P., L.O.M, S.M.A.T, M.E.G.S, F.L.M., J.C.C., E.S., L.C.B., C.M.D.S., N.F.D.M., C.H.O., A.J.J.S., S.B.V., M.A.M.G., G.G.M., L.O.M and M.A.B.A. Analyzed the data: M.S.A., F.S.C., A.A.S.C., F.V.S.A., F.L.M., A.P.S., J.C.C., E.S., D.S.T., A.P.M.R., B.M.R., A.O.D.T, P.M.R., and M.A.B.A. Contributed reagents/materials/analysis tools: A.C.F., B.M.R., P.M.R., A.O.D.T, D.C.C.C and M.A.B.A. Contributed to the writing of the manuscript: M.S.A., F.S.C., A.A.S.C., M.A.B.A., F.L.M., A.P.S., J.C.C., E.S., A.O.D.T., D.S.T., S.B.V., A.P.M.R., B.M.R., P.M.R. and F.V.S.A.

Funding: This work was funded by grants from Conselho Nacional de Desenvolvimento Científico e Tecnológico and Departamento de Ciência e Tecnologia of Secretaria de Ciência, Tecnologia e Insumos Estratégicos of Ministério da Saúde (CNPq/Decit/SCTIE/MS grant number 443215/2019-7).

Acknowledgments: We acknowledge the contributions of the Division of Environmental Health Surveillance from Minas Gerais State. The authors would like to thank the effort of the MG Yellow Fever Surveillance Team that was at the forefront of the preparation to face the arrival of the virus in the state as well as in field investigations. To Beatrízio Rodrigues Almeida, Hermes Almeida and Joselio Ribeiro Paraíso for their valuable help during the field work. To Aline Tátila Ferreira for her help in creating images. We are also grateful to countless colleagues from municipalities' health departments, who conducted the investigation of epizootics collecting samples in the field and to the Ministry of Health's Arbovirus Surveillance Team. The Yellow Fever Brazil project (Febre Amarela BR: https://www.febreamarelabr.com.br/) is supported by grants from Conselho Nacional de Desenvolvimento Científico e Tecnológico and Departamento de Ciência e Tecnologia of Secretaria de Ciência, Tecnologia e Insumos Estratégicos of Ministério da Saúde (CNPq/Decit/SCTIE/MS grant number 443215/2019-7). M.S.A. is granted a post-doctoral scholarship (DTI-A) from CNPq. P.M.R. is a CNPq research fellow.

Conflicts of Interest: The authors declare no conflict of interest.

\section{4) References}

Abreu FVS de, Delatorre E, dos Santos AAC, Ferreira-de-Brito A, de Castro MG, Ribeiro IP, Furtado ND, Vargas WP, Ribeiro MS, Meneguete P, Bonaldo MC, Bello G, Lourenço-de-Oliveira R, Abreu FVS de, Delatorre E, dos Santos AAC, Ferreira-de-Brito A, de Castro MG, Ribeiro IP, Furtado ND, Vargas WP, Ribeiro MS, Meneguete P, Bonaldo MC, Bello G, Lourenço-de-Oliveira R (2019a) Combination of surveillance tools reveals that Yellow Fever virus can remain in the same Atlantic Forest area at least for three transmission seasons. Mem Inst 
Oswaldo Cruz 114. https://doi.org/10.1590/0074-02760190076

Abreu FVS de, Ribeiro IP, Ferreira-de-Brito A, Santos AAC dos, Miranda RM de,

Bonelly I de S, Neves MSAS, Bersot MI, Santos TP dos, Gomes MQ, Silva JL da, Romano APM, Carvalho RG, Said RF do C, Ribeiro MS, Laperrière R da C, Fonseca EOL, Falqueto A, Paupy C, Failloux A-B, Moutailler S, Castro MG de, Gómez MM, Motta M de A, Bonaldo MC, Lourenço-de-Oliveira R (2019b)

Haemagogus leucocelaenus and Haemagogus janthinomys are the primary vectors in the major yellow fever outbreak in Brazil, 2016-2018. Emerg Microbes Infect 8:218-231. https://doi.org/10.1080/22221751.2019.1568180

Abreu FVS, dos Santos E, Gomes MQ, Vargas WP, Oliveira Passos PH, Nunes e Silva C, Araújo PC, Pires JR, Romano APM, Teixeira DS, Lourenço-de-Oliveira R (2019c) Capture of Alouatta guariba clamitans for the surveillance of sylvatic yellow fever and zoonotic malaria: Which is the best strategy in the tropical Atlantic Forest? Am J Primatol 81:e23000. https://doi.org/10.1002/ajp.23000

Almeida MAB, Santos E, Cardoso JC, Fonseca DF, Noll CA, Silveira VR, Maeda AY, Souza RP, Kanamura C, Brasil RA (2012) Yellow fever outbreak affecting Alouatta populations in southern Brazil (Rio Grande do Sul State), 2008-2009. Am J Primatol 74:68-76. https://doi.org/10.1002/ajp.21010

Andrade M de S, Campos FS, Campos AAS, Abreu FVS, Melo FL, Sevá A da P, Cardoso J da C, Santos E Dos, Born LC, Silva CMD da, Müller NFD, Oliveira CH de, Silva AJJ da, Simonini-Teixeira D, Bernal-Valle S, Mares-Guia MAMM, Albuquerque GR, Romano APM, Franco AC, Ribeiro BM, Roehe PM, Almeida MAB de (2021) Real-Time Genomic Surveillance during the 2021 Re-Emergence of the Yellow Fever Virus in Rio Grande do Sul State and Brazil. Viruses 2021, Vol 13, Page 1976 13:1976 . https://doi.org/10.3390/V13101976

Berthet, M, Mesbahi, G, Duvot, G, Zuberbühler, K, Cäsar, C, \& Bicca-Marques, JC (2021) Dramatic decline in a titi monkey population after the 2016-2018 sylvatic yellow fever outbreak in Brazil. Am. J. Primatol., e23335.

https://doi.org/10.1002/ajp.23335

Bicca-Marques, JC, Calegaro-Marques, C, Rylands, AB, Strier, KB, Mittermeier, RA, Almeida, MAB, Castro, PHG, Chaves, OM, Ferraz, LP, Fortes, VB, Hirano, ZMB, Jerusalinsky, L, Kowalewski, M, Martins, WP, Melo, FR, Mendes, SL, Neves, LG, Passos, FC, Port-Carvalho, M, Ribeiro, S, Romano, APM, Ruiz-Miranda, CR, Santos, EO, Souza Jr, JC, Teixeira, DS (2017) Yellow fever threatens Atlantic Forest primates. Science Advances, 3, e1600946 tab-e-letters.

Brasil (2017) Guia de vigilância de epizootias em primatas não humanos e entomologia aplicada à vigilância da febre amarela, 2nd edn. Ministério da Saúde, Brasília

Camargo-Neves VLF de, Poletto DW, Rodas LAC, Pachioli ML, Cardoso RP, Scandar SAS, Sampaio SMP, Koyanagui PH, Botti M V., Mucci LF, Gomes A de C (2005) Entomological investigation of a sylvatic yellow fever area in São Paulo State, Brazil. Cad Saude Publica 21:1278-1286. https://doi.org/10.1590/S0102311X2005000400031

Causey OR, Hughes TP, Laemmert HW (1949) The Invasion of Small Forests by Yellow Fever Virus as Indicated by Immunity in Cebus Monkeys 1. Am J Trop Med Hyg s1-29:555-565. https://doi.org/10.4269/ajtmh.1949.s1-29.555 
Chame M, Barbosa HJC, Gadelha LMR, Augusto DA, Krempser E, Abdalla L (2019) SISS-Geo: Leveraging Citizen Science to Monitor Wildlife Health Risks in Brazil. J Healthc Informatics Res 3:414-440. https://doi.org/10.1007/s41666-019-00055-2

Costa ZGA (2005) Estudo das características epidemiológicas da febre amarela no brasil , nas áreas fora da amazônia legal, no período de 1999 a 2003. Thesis.

Cunha M dos P, Duarte-Neto AN, Pour SZ, Ortiz-Baez AS, Černý J, Pereira BB de S, Braconi CT, Ho YL, Perondi B, Sztajnbok J, Alves VAF, Dolhnikoff M, Holmes EC, Saldiva PHN, Zanotto PM de A (2019) Origin of the São Paulo Yellow Fever epidemic of 2017-2018 revealed through molecular epidemiological analysis of fatal cases. Sci Rep 9. https://doi.org/10.1038/s41598-019-56650-1

de Souza RP, Petrella S, Coimbra TLM, Maeda AY, Rocco IM, Bisordi I, Silveira VR, Pereira LE, Suzuki A, Santos Silva SJ Dos, Silva FG, Salvador FS, Tubaki RM, Menezes RT, Pereira M, Bergo ES, Hoffmann RC, Spinola RMF, Tengan CH, Siciliano MM (2011) Isolation of Yellow Fever virus (YFV) from naturally infected Haemagogus (Conopostegus) leucocelaenus (Diptera, Culicidae) in São Paulo state, Brazil, 2009. Rev Inst Med Trop Sao Paulo 53:133-139. https://doi.org/10.1590/S0036-46652011000300004

Delatorre E, Santos De Abreu FV, Ribeiro IP, Gómez MM, Cunha Dos Santos AA, Ferreira-De-Brito A, Alberto Santos Neves MS, Bonelly I, De Miranda RM, Furtado ND, Souza Raphael LM, Fernandes Da Silva LDF, De Castro MG, Ramos DG, Martins Romano AP, Kallás EG, Paulo Vicente AC, Bello G, Lourenço-DeOliveira R, Cristina Bonaldo M (2019) Distinct YFV Lineages Co-circulated in the Central-Western and Southeastern Brazilian Regions from 2015 to 2018. Front Microbiol 10. https://doi.org/10.3389/fmicb.2019.01079

Dietz, JM, Hankerson, SJ, Alexandre, BR, Henry, MD, Martins, AF, Ferraz, LP, RuizMiranda, CR (2019) Yellow fever in Brazil threatens successful recovery of Endangered golden lion tamarins. Scientific Reports, 9, 12926.

Faria NR, Kraemer MUG, Hill SC, Goes de Jesus J, Aguiar RS, Iani FCM, Xavier J, Quick J, du Plessis L, Dellicour S, Thézé J, Carvalho RDO, Baele G, Wu CH, Silveira PP, Arruda MB, Pereira MA, Pereira GC, Lourenço J, Obolski U, Abade L, Vasylyeva TI, Giovanetti M, Yi D, Weiss DJ, Wint GRW, Shearer FM, Funk S, Nikolay B, Fonseca V, Adelino TER, Oliveira MAA, Silva MVF, Sacchetto L, Figueiredo PO, Rezende IM, Mello EM, Said RFC, Santos DA, Ferraz ML, Brito MG, Santana LF, Menezes MT, Brindeiro RM, Tanuri A, Dos Santos FCP, Cunha MS, Nogueira JS, Rocco IM, da Costa AC, Komninakis SCV, Azevedo V, Chieppe AO, Araujo ESM, Mendonça MCL, Dos Santos CC, Dos Santos CD, Mares-Guia AM, Nogueira RMR, Sequeira PC, Abreu RG, Garcia MHO, Abreu AL, Okumoto O, Kroon EG, de Albuquerque CFC, Lewandowski K, Pullan ST, Carroll M, de Oliveira T, Sabino EC, Souza RP, Suchard MA, Lemey P, Trindade GS, Drumond BP, Filippis AMB, Loman NJ, Cauchemez S, Alcantara LCJ, Pybus OG (2018) Genomic and epidemiological monitoring of yellow fever virus transmission potential. Science. 31;361(6405):894-899. https:// doi.org/10.1126/science.aat7115.

Fernandes NCC de A, Cunha MS, Guerra JM, Réssio RA, Cirqueira C dos S, D’Andretta Iglezias S, de Carvalho J, Araujo ELL, Catão-Dias JL, Díaz-Delgado J 
(2017) Outbreak of yellow fever among nonhuman primates, Espirito Santo, Brazil, 2017. Emerg Infect Dis 23:2038-2041.

https://doi.org/10.3201/eid2312.170685

Fernandes et al., 2021 - Differential Yellow Fever Susceptibility in New World

Nonhuman Primates, Comparison with Humans, and Implications for Surveillance.

https://wwwnc.cdc.gov/eid/article/27/1/19-1220_article

Franco O (1969) História da Febre Amarela no Brasil. Departamento Nacional de Endemias Rurais, Rio de Janeiro.

Goes de Jesus J, Gräf T, Giovanetti M, Mares-Guia MA, Xavier J, Lima Maia M, Fonseca V, Fabri A, dos Santos RF, Mota Pereira F, Ferraz Oliveira Santos L, Reboredo de Oliveira da Silva L, Pereira Gusmão Maia Z, Gomes Cerqueira JX, Thèze J, Abade L, Cordeiro M de CS, Torquato SSC, Santana EB, de Jesus Silva NS, Dourado RSO, Alves AB, do Socorro Guedes A, da Silva Filho PM, Rodrigues Faria N, de Albuquerque CFC, de Abreu AL, Martins Romano AP, Croda J, do Carmo Said RF, Cunha GM, da Fonseca Cerqueira JM, Mello AL e S de, de Filippis AMB, Alcantara LCJ (2020) Yellow fever transmission in nonhuman primates, Bahia, Northeastern Brazil. PLoS Negl Trop Dis 14:e0008405. https://doi.org/10.1371/journal.pntd.0008405

Gómez MM, Abreu FVS de, Santos AAC dos, Mello IS de, Santos MP, Ribeiro IP, Ferreira-de-Brito A, Miranda RM de, Castro MG de, Ribeiro MS, Laterrière Junior R da C, Aguiar SF, Meira GLS, Antunes D, Torres PHM, Mir D, Vicente ACP, Guimarães ACR, Caffarena ER, Bello G, Lourenço-de-Oliveira R, Bonaldo MC (2018) Genomic and structural features of the yellow fever virus from the 20162017 Brazilian outbreak. J Gen Virol 99:536-548. https://doi.org/10.1099/jgv.0.001033

Holzmann I, Agostini I, Areta JI, Ferreyra H, Beldomenico P, Di Bitetti MS (2010) Impact of yellow fever outbreaks on two howler monkey species ( Alouatta guariba clamitans and A. caraya) in Misiones, Argentina. Am J Primatol 72:n/an/a. https://doi.org/10.1002/ajp.20796

Kazutaka Katoh, Daron M. Standley (2013) MAFFT Multiple Sequence Alignment Software Version 7: Improvements in Performance and Usability. Molecular Biology and Evolution, 30:4:772-780, https://doi.org/10.1093/molbev/mst010

Mares-Guia et al., 2020 - Yellow fever epizootics in non-human primates, Southeast and Northeast Brazil (2017 and 2018).

https://parasitesandvectors.biomedcentral.com/articles/10.1186/s13071-020-3966-X

Minas Gerais, Secretaria de Saúde SES-MG (2018) Boletim epidemiológico especial Encerramento do período sazonal Julho/2017 a Junho/2018 - Febre Amarela Silvestre em Minas Gerais 18/10/2018. Available on: https://www.saude.mg.gov.br/images/noticias_e_eventos/000_2018/BoletinsEpide miologicos/Boletim_-_Febre_Amarela_2018_-_Consolidado_V3.pdf. Accessed 20 november 2021.

Minas Gerais, Secretaria de Saúde SES-MG (2019) Febre Amarela Silvestre em Minas Gerais 19/02/2019. Available on: https://www.saude.mg.gov.br/images/noticias_e_eventos/000_2019/jane_fev_mar/ Febre_Amarela/Boletim_atualiza\%C3\%A7\%C3\%A3o_FA_12-02-2019.pdf. Accessed 11 october 2021. 
Minas Gerais, Secretaria de Saúde SES-MG (2021) NOTA INFORMATIVA SES/SUBVS-SVE-DVAT-CEVARB 1877/2021. Available on: https://www.saude.mg.gov.br/images/noticias_e_eventos/000_2021/SEI_1320.01.0 038355_2021_82\%20NI\%20SES\%201877-2021\%20-\%20ALERTA\%20FA.pdf Accessed 11 october 2021.

Ministry of Health Brazil. In Ministry of Health Data on Epizootics and Cases in Humans Caused by the Yellow Fever Virus in Brazil (2014-2021); Information access request number: 25072.015631/2020-62.; Ministry of Health: Rio de Janeiro, Brazil, 2021.

Monath TP, Vasconcelos PFC (2015) Yellow fever. J Clin Virol 64:160-173. https://doi.org/10.1016/j.jcv.2014.08.030

Moreno ES, Agostini I, Holzmann I, Di Bitetti MS, Oklander LI, Kowalewski MM, Beldomenico PM, Goenaga S, Martínez M, Lestani E, Desbiez ALJ, Miller P (2015) Yellow fever impact on brown howler monkeys (Alouatta guariba clamitans) in Argentina: A metamodelling approach based on population viability analysis and epidemiological dynamics. Mem Inst Oswaldo Cruz 110:865-876. https://doi.org/10.1590/0074-02760150075

Moreno ES, Rocco IM, Bergo ES, Brasil RA, Siciliano MM, Suzuki A, Silveira VR, Bisordi I, de Souza RP (2011) Reemergência de febre amarela: Detecção de transmissão no estado de São Paulo, Brasil, 2008. Rev Soc Bras Med Trop 44:290296. https://doi.org/10.1590/S0037-86822011005000041

Pinheiro GG, Rocha MN, de Oliveira MA, Moreira LA, Andrade Filho JD (2019) Detection of Yellow Fever Virus in Sylvatic Mosquitoes during Disease Outbreaks of 2017-2018 in Minas Gerais State, Brazil. Insects 10:136. https://doi.org/10.3390/insects10050136

Possas C, Lourenço-de-oliveira R, Tauil PL, Pinheiro FDP, Pissinatti A, Venâncio R, Freire M, Martins RM, Homma A (2018) Yellow fever outbreak in Brazil : the puzzle of rapid viral spread and challenges for immunisation. Mem Inst Oswaldo Cruz 113:1-12. https://doi.org/10.1590/0074-02760180278

Ribeiro M, Antunes CMDF (2009) Febre amarela: Estudo de um surto. Rev Soc Bras Med Trop 42:523-531. https://doi.org/10.1590/S0037-86822009000500009

Romano APM, Costa ZGA, Ramos DG, Andrade MA, de Jayme VS, de Almeida MAB, Vettorello KC, Mascheretti M, Flannery B (2014) Yellow Fever Outbreaks in Unvaccinated Populations, Brazil, 2008-2009. PLoS Negl Trop Dis 8:18-21. https://doi.org/10.1371/journal.pntd.0002740

Strier KB, Tabacow FP, de Possamai CB, Ferreira AIG, Nery MS, de Melo FR, Mendes SL (2019) Status of the northern muriqui (Brachyteles hypoxanthus) in the time of yellow fever. Primates 60:21-28. https://doi.org/10.1007/s10329-018-0701-8

Vasconcelos PFC, Costa ZG, Travassos Da Rosa ES, Luna E, Rodrigues SG, Barros VLRS, Dias JP, Monteiro HAO, Oliva OFP, Vasconcelos HB, Oliveira RC, Sousa MRS, Barbosa Da Silva J, Cruz ACR, Martins EC, Travassos Da Rosa JFS (2001) Epidemic of jungle yellow fever in Brazil, 2000: Implications of climatic alterations in disease spread. J Med Virol 65:598-604. https://doi.org/10.1002/jmv.2078 
Vasconcelos PFC, Rodrigues SG, Degallier N, Moraes MAP, Travassos Da Rosa JFS, Travassos Da Rosa ES, Mondet B, Barros VLRS, Travassos Da Rosa APA (1997) An epidemic of sylvatic yellow fever in the southeast region of Maranhao State, Brazil, 1993-1994: Epidemiologic and entomologic findings. Am J Trop Med Hyg 57:132-137. https://doi.org/10.4269/ajtmh.1997.57.132

Vasconcelos PF, Sperb AF, Monteiro HA, Torres MA, Sousa MR, Vasconcelos HB, Mardini LB, Rodrigues SG. Isolations of yellow fever virus from Haemagogus leucocelaenus in Rio Grande do Sul State, Brazil. Trans R Soc Trop Med Hyg. 2003 Jan-Feb;97(1):60-2. doi: 10.1016/s0035-9203(03)90023-x. 